\title{
An econometric analysis of the effectiveness of fiscal and monetary policies in India
}

\author{
Anand Nadar
}

Bennett University

March, 2021

\section{Abstract:}

This study investigate the effectiveness of fiscal policy and monetary policy in India. We collected the time series data for India ranging from 1960 to 2019 from World Development Indicator (WDI). We applied the bound test to check the long-run relationship between fiscal policy, monetary policy and economic growth. The short-run and long-run effects of fiscal policy and monetary policy have been estimated using ARDL models. The results showed that there is a long-run relationship between fiscal and monetary policies with economic growth. The estimated short-run coefficients indicated that a few immediate short run impact of fiscal and monetary policies are insignificant. However, the shortrun impacts become significant as time passes. The long-run results suggested that the long-run impact of both fiscal and monetary policies on economic growth are positive and significant. More specifically, the GDP level increases if the money supply and government expenditure increase (Expansionary fiscal and monetary policies). On the other hand, the GDP level decrease if the money supply and government expenditure decrease (contractionary fiscal and monetary policies). Therefore, this study recommend to use expansionary policies to spur the Indian economy.

\section{Keyword: ARDL; Cointegration; Fiscal policy; India; Monetary policy}

\section{Introduction}

In general, major macroeconomic policies include monetary policy, fiscal policy, income policy, development policy, stabilization policy, and employment policy. However, fiscal policy and monetary policy are the two most relevant macroeconomic policies and other policies relating to economic development, stability and welfare are the parts of these two policies (Bishai \& Kung, 2007), (Cannon, 2004).

Policy instruments are the variables which are under direct control of the authorities and can be changed at the discretion of the government. For example, central bank's bank rate or repo rate, cash reserve ratio (CRR), statutory liquidity ratio (SLR), prime lending rate (PLR), tax rate and the level of public expenditure are the main policy instruments. Policyinstruments are also called as instrumental 
variables (Gertler \& Karadi, 2015). There are two types of policy instruments to be classified: monetary policy instruments and fiscal policy instruments.

In more general terms, tax policy can be described as follows. Fiscal Policy is the Government's initiative to make discretionary adjustments in its spending, taxation and borrowing patterns and levels to achieve certain economic objectives, such as economic development, jobs, income equality, and economic growth stability .

Fiscal policies include (I) government spending, (ii) taxes and (iii) public loans and (iv) funding of deficits. Discretionary adjustments in fiscal instruments lead to a shift in the target fiscal variables. In particular, the adjustments to the fiscal target variables are driven by actual variables such as disposable income, consumer spending, savings, investment, and people's wealth. Clearly, economic control fiscal policies impact almost all real macro variables and thus influence a wide variety. It affects the economic options of those who have taxable revenues, purchase taxablegoods and services, save and invest or have wealth as public bonds.

Government expenditure includes overall government expenditure for goods and services, wage payment to officials, public procurement, infrastructure growth, transfer payments (e.g., pensions, subsidies, unemployment allowance, grants and aid, payments of interest, and amortization of loans). The scale and composition of government spending in terms of financial capital is a matter for the discretion of the Government. Public costs are an incentive to the economy: the aggregate de mand is raised. The total impact of public spending on economy depends on the funding and the multiplier effect of government spending.

Monetary policy instruments are (i) bank rate or repo rate, (ii) open market operations (OMO), (iii) cash reserve ratio (CRR), and (iv) specific credit controls. Monetary instruments have an effect on demand and money supply. In essence, they work for the flow of money between the banks and the public and the banks. In particular, monetary control instruments have an important influence on the flow of institutional credit. The demand for money by the people is increased or decreased. Since money is an exchange medium, currency controls influence the real variables.

Taxation as another fiscal instrument. governments use taxation as a means to finance spending. But higher taxes with voters are usually controversial. However, they normally want to spend more on schooling, security and healthcare. So a hard bal ancing act is not followed by most governments; they always spend more on taxation than they do receive. These strategies are therefore mainly used to manage their spending and allow more flexibility at a lower level of political costs. Higher taxes, however, do not inherently mean increased incomes, as the Laffer Curve shows. Governments also need to take a fine line to maximize income (Ferris, 2013).

At the same time, more revenue means less for public expenditure in private hands. However, reducing taxes in a recession is much easier than reducing the economic boom. This is because there are less employees and smaller business profits (low revenue tax revenues) (lower corporate tax receipts). The chance cost is also smaller. 
When deciding on fiscal policy, governments have many goals in mind. Although they are not al ways taken into account in the same way (Davig \& Leeper, 2011). Some governments, such as Greece, may, for example, be forced to manage debtover full employment. Likewise, a country in a healthy financial situation may want to target full employment over its low debt level. Governments will prefer one target over the other.

\section{Fiscal policy and economy}

Fiscal policies can affect the economy in the following ways (Balducci, 2005):

1. Full employment .

One of the key goals of governments is to keep citizens working. The governments benefit not only from higher taxation, but also from reduced social security costs (Rendahl, 2016). An expansionary strategy will aim at investing directly in infrastructure that creates jobs. It could also reduce taxes in order to provide customers with more funds to generate jobs indirectly through sales.

2. The economic growth

The economy is growing more stable for its people as a whole. That is therefore an essential goal. Governments ought to be vigilant at the same time. In the long run, an ambitious expanded fiscal policy could prove harmful. Greece is just an example to look at (Balducci, 2005).

Economic development is a comprehensible goal, but alongside prosperity it al so has to be considered. High government expenditure, for example, can lead to inflation. Excessive expenditure can create high debt levels and inflation rates which destroy the country's riches.

\section{Debt Control}

It's not always wrong to run a budget deficit. It causes more and more debt over time, however. If inflation and tax revenues do not lift it, the nation faces a debt level that is unsustainable. This is regulated by a rational fiscal policy until drastic action is required.

\section{Inflation control}

When an economy grows strongly, high inflation will occur (this may also depend on monetary policy). As $2 \%$ is usually the goal, anything above this is a concern: especially if it is consistently above. While inflation is a monetary phenomenon, governments are taking measures to stop it. That said, if the money supply has been loose, there is little fiscal policy to do. However, policymakers are trying to lower disposable incomes and therefore consumption by rising taxes (Zhu \& Warner, 2019).

\section{Redistribution}

The government's other objective is to shift riches from the wealthy to the poor. Often higher taxes on wealthy people may lead to high revenue, but that is not always the case. Evasion and evasion can 
happen or they can just leave the country, actually. Although small incremental increments can not have a big short-term effect.

\section{Civil policy}

Fiscal policies are inevitablya political weapon, used to some degree by many incumbents. Fiscal policy relief and higher expenditure will also win over some "floating voters."

Indeed, fiscal policy efficiency is constrained by the factors below. First of all, to formulate an adequate fiscal policy, the goal variables, namely GNP, consumption, costs, investment and its factors, technology shifts, etc. must be reliably forecast. Secondly, a complex multiplier rate can assess the aggregate impact of policy instruments adjustments - government expenditure and taxation. First of all, it is a very difficult job to predict, if not impossible, dynamic multipliers in themselves, because of customer behavior volatility. Secondly, the working time is lagging behind the dynamic multiplier. Therefore, when one policy reform has its full effect, economic conditions will change and a further change in fiscal policy will be necessary. Further monetary policy reforms produce more issues than they fix, if they resolve anything. Third, as stated before, in cases of discretionary fiscal policy, decisionmaking and implementation lags are both uncertain about the functioning and effectiveness of fiscal policies. Such confusion actually poses a mystery as to 'why tax policy?' Fourth, fiscal policy functioning and effectiveness are severely limited in underdeveloped countries by I low income levels, (ii) low population share in taxable income categories, (iii) broad non-monetized sectors and (iv) all prevalent bribery and administration inefficacy, particularly in fiscal collection systems. Fifthly, governments also have to rely on internal and external borrowings for deficit financing in countries which are largely dependent on fiscal policiesfor their economical management and have inadequate fiscal sphere. The unwanted economic implications for these funding strategies have also been illustrated. Such an impact limits the use of monetary policy. The debt trap is close to unsustainable borrowing. The Mexican, Brazilian and Indian cases are in view. The rate of inflation is accelerated by deficit funding beyond the absorption potential of the economy. Another form of economic issue is created by inflation. More importantly, this form of deficit-funded government spending is said to overwhelm private investment.

\section{Monetary policy and economy}

Monetary policy can affect the economy in the following ways.

1. Saving induction: Savings are essential for the formation of capital, which is an essential condition for economic development. Monetary policy in an underdeveloped world helps to promote savings, mobilize them and invest in productivity (Bernanke \& Blinder, 1988). Appropriate banking institutions must be provided by the monetary authority and later used for investment purposes. The monetary authorities have multiple incentives to provide savers, in the form of high interest rates, protection of deposits, etc. In order to encourage savings (Cukierman, 2013).

2. Savings investment: not only by setting up new institutions but can be overcome by saving productive savings investments" is "the problem of insufficient savings. Unless and until savings are used in productive investment programs, the economic growth target cannot be achieved. As there are no profitable productive activities, lack of entrepreneurial capacity and low marginal efficacité of resources, the rate of investment in underdevel oped countries is very low. In such a case, the central bank may use a low-cost strategy to encourage investments (Cukierman, 2013). 
3. Appropriate policies on the rate of interest: The rate of interest structures in underdeveloped countries do not necessarily lead to economic development - interest rates not only vary from each other in accordance with time schedules but differ in various regions and business activities as well (Skidelsky, 2019). As is commonly seen in underdeveloped countries, high interest rates deter public and private investments. Therefore, the monetary authority formulate such a policy regarding the interest rate that can encourage investors to obtain more loans and advances commercial and other financial institutions.

4. Maintenance and monetary equilibrium. Monetary policy should be geared to the fair treatment of demand for capital and money supplies in an underdeveloped region. In the initial stages of economic development, credit facilities must be expanded, but the central bank must enforce credit restraints of various kinds when a certain degree of growth is reached. It is however quite difficult in practice to tell when credit limits for control of the supply of money should be put on the mone tary authority (Frazer \& Ward, 1967).

5. To favor Balancing Payments: the majority of undeveloped countries must, at the initial stage of their growth, import capital goods, machinery, equipment and technical expertise. The ir imports thus outweigh their exports and unfavorable are the balance of payments. Monetary policy should aim to preserve exchange rate stability and remove balance of payments imbalances.

6. Price stability: In underdeveloped countries internal price sta bility is a critical monetary policy goal. Violent internal price fluctuations not only interrupt the smooth functioning of the economy, but also result in instability and social inequality. Whilst inflation causes huge difficulties for salaried workers and customers, deflation is catastrophic for businessmen and workers alike. Growing labor and material costs often raise the costs of many projects that negatively impact the growth rate.

Developing country monetary policy limitations: monetary policy can play a very critical and important role in developing countries' economic growth. However, there are some factors limiting the effectiveness of the monetary policy, the most important are (Bruno \& Shin, 2015):

1. Underdeveloped monetary and capital markets: most developing states d o not have the capital and capital markets completely developed and organized. Without these established money markets, the various central bank credit management policies cannot be effectively implemented .

2. Lack of integrated interest rate structure: in developed countries, the unorganized banking sector accounts for a significant portion of total financial capital. The central bank does not affect the market rate of interest by adjustments to the bank's rate in the absence of an integrated and well-organized rate structure. Indeed, any increase or decrease in bank rate should be reflected in an increase or decrease in the interest rate on the economy, but in developing countries it does not happen.

3. People's banking habits: most of the exchange transactions are carried out using money in developed countries. Credit instruments are seldom used by people to exchange transactions. 
4. The Commercial Bank's lack of co-operation: Commercial banks are the institutions that support the implementation of the central bank's monetary policy. However, commercial banks in developed countries do not provide the central bank with adequate cooperation and, in some cases, often fail to comply with Central Bank directives.

5. Literacy and social impediments: Mass analphabets, superstition, dogmatism and other social evils endure most developed countries. The importance of banking institutions is not understood. They neither hold their deposits with the banks nor use banks' loans and progress opportunities. The effectiveness of monetary policy depends on the widespread banking institutions, people's banking habits, adequate credit facility growth, sufficient bank deposits, business skills, etc.

It was restricted by the limits of monetary policy. The effectiveness of monetary policy depends on certain variables, namely the lag in factor reaction, forecast issues, financial intermediaries' non -bank reactions and capital markets' underdevelopment. These factors are referred to as the monetary policy limiting factors.

\section{Literature review}

Using a systemic VAR review of real GDP, tax revenues, and government expenses, (Kuttner \& Posen, 2002)examines the efficacy of Japanese fiscal policy from 1976 to 1999. They discovered that tax cuts and public works spending, whether in the form of tax cuts or public works spending, had major stimulative effects. They measure that the multiplier on tax cuts is around $25 \%$ higher at a four-year horizon than the multiplier on public works investment, despite the fact that both are far in exce ss of one, using a modern method of calculating policy multipliers from structural VARs. A historical decomposition shows that Japanese fiscal policy was contractionary for most of the 1990s, and that fiscal policy shocks account for a large portion of the variance in growth; as a result, the majority of the rise in public debt can be attributed to declining tax revenues due to the recession. They find small evidence of Ricardian effects as they examine savings behavior directly, which is insufficient to counteract the short-term effects of discretionary fiscal policy.

A research by (Arestis \& Sawyer, 2004) considers the significance of this shift in the nature of monetary policy. This enables us to question the effectiveness of monetary policy, and to explore the role of fiscal policy. They examine these questions from the point of view of the "new consensus" in monetary economics and suggest that it is rather limited in its analysis. When the anal ysis is broadened out to embrace empirical issues and evidence the clear conclusion emerges that monetary policy is relatively impotent. The role of fiscal policy is also considered, and they argue that fiscal policy (under specified conditions) remains a powerful tool for macroeconomic policy. This is particularly an apt conclusion under current economic conditions.

(Jha, Mallick, Park, \& Quising, 2014) look at it from the perspective of developing Asia, where many countries used fiscal stimulus to boost domestic demand during the global financial crisis. After the crisis, economic conditions stabilized, but Asia's growth has slowed since then. They look at historical data from ten emerging Asian countries to see whether countercyclical fiscal policies will help the region develop in the future. Their research focuses on detecting shocks by limiting the contemporaneous relationship between fiscal and non-fiscal variables. Their most important and clear finding is that tax cuts have a greater countercyclical effect on productivity in developing Asia than 
government spending. As long as fiscal stabilization is not jeopardized, this mean s that countercyclical tax changes are possible.

In order to examine the effects of two separate fiscal laws on the efficacy of fiscal policy, (Zeyneloglu, 2018) employs a dynamic stochastic general equilibrium (DSGE) system with imperfect competition and nominal rigidities. The first rule is known as the golden rule of publicfinance, and it provides for an increase in the share of public expenditure in overall government spending while restricting the use of public debt solely for investment purposes. The second rule does not change the division of government spending between expenditure and consumption, but it does allow for public consumption to be funded by debt. In comparison to the second law, the numerical findings indicate that fiscal expansion under the golden rule leads to a higher growth in productivity while retaining a low level of public debt. Furthermore, in the medium run, the difference between the production responses under the two fiscal rules grows, meaning that the benefits of a golden rule-based fiscal policy are greater, especially in the medium run.

(Biljana \& Tamara, 2013) used unit root and cointegration analyses, as well as regression analysis, on a series of quarterly data for the years 2003-2012 to assess the impact of fiscal and monetary policy on economic activity in Serbia. The findings suggest that, as opposed to fiscal policy, monetary policy is more effective at stimulating economic development. As a result, the ultimate inference is that the government should pay more attention to fiscal policy in the future in order to increase its performance.

The purpose of (Özer \& Karagöl, 2018) was analyzing the efficacy of fiscal and monetary policies in promoting economic growth in Turkey between 1998 and 2016, and then determining which of these two policies is more powerful in promoting economic growth in Turkey between 1998 and 2016. They use time series econometric techniques including ARDL Bounds testing, structural break unit root tests, and Granger causality tests to investigate the efficacy of monetary and fiscal policies in terms of growth. The monetary policy variable has only short-run effects on growth; however, it does not cause any Granger causality. Fiscal policy, on the other hand, has a long-term major impact on development and causes it. As a result, during the review period, fiscal policy tends to be more success ful than monetary policy, suggesting that both policies should be rethought in Turkey. This research is the first to look at the relative effectiveness of economic policies on growth in Turkey, taking into account both the methods used and the time period chosen.

Cointegration and error correction modeling techniques were used in (Ajisafe \& Folorunso, 2002) to assess the relative effectiveness of monetaryand fiscal policy on economic activity in Nigeria. The time series properties of the variables were investigated using annual series data from 1970 to 1998, primarily from the CBN Statistical Bulletin, using a unit root test. According to their findings, monetary policy, rather than fiscal policy, has a major effect on Nigerian economic activity. The government's focus on fiscal policy has caused the Nigerian economy to become more distorted. They do believe, however, that monetary and fiscal policies should complement one another.

(Hur, 2007) has shown that regardless of economic interventions, tax reductions, or spending increases, or methods of detecting shocks, the efficacy of fiscal policy in Korea is not substantially 
known. Although the impact of fiscal policy has been established in some situations, it is either very small in magnitude, phases out rapidly, or is triggered by linear detrending. The fact that fiscal policy makes such a small contribution to economicstability raises a lot of questions for future study. There are many reasons for fiscal policy's weak performance as a means of stimulating the Koreane conomy. Acceptance of the latest classical argument will be the first and easiest guess. However, the mystery of why the efficacy of fiscal policy, which has been proved in other nations, has been refuted in Korea remains unresolved. In either case, their paper concludes with results that are diametrically opposed to the widely held Keynesian theory. Even then, it is still too soon to leave it in favor of the modern classical theory. Fiscal policy ineffectiveness can be seen in Ricardian equivalence, for ex ample. It does not cover any of the fiscal policy transmission networks, which their VAR configuration evaluates in total. Their setup, on the other hand, fails to pinpoint how the Ricardian equivalence statement functions in a sector. As a result of this paper's accomplishments, it is more desirable to continue their study in both of the following directions: theoretically verifying other potential monetary policy transmission channels and empirically comparing the magnitudes of their effect on the macro economy.

In Zimbabwe, (Simon, 2012) explores the effectiveness of fiscal policy in stimulating economic development. The research used annual data from 1980 to 2010. The series' unit roots were analyzed using the Augmented Dickey-Fuller method, and the cointegration test was performed using the Johansen Approach. To account for short-run dynamics, error-correction models were estimated. The findings show that government consumption expenditure and income tax had a positive effect on economic growth during the study period, but that government capital expenditure had a negative impact, and that there is a long-run relationship between them, as confirmed by the cointegration test.

(Jawadi, Mallick, \& Sousa, 2016) examine the macroeconomic effects of fiscal and monetary policy shocks in five major emerging market economies: Brazil, Russia, India, China, and South Africa, using a Panel Vector Auto-Regressive (PVAR) model (BRICS). They demonstrate that monetary tightening reduces real economic activity and tightens liquidity market conditions, while government spending shocks have significant Keynesian effects. They also discover evidence for an accommodating stance between fiscal and monetary policy, which is critical for economic and political decision-making. Even after accounting for times of severe uncertainty, such as global and financial crises, the researchers' findings are strong.

(Khemani, 2007) compares the effect of partisan politics on two forms of fiscal transfers to states in the Indian federation over a period of time, 1972-1995, to see whether delegation to an autonomous body makes a difference. Although transfers determined by the central political executive are distributed to benefit particular states that are politically significant for the central governing party, transfers assigned to an autonomous agency serve to limit such partisan effect. 


\section{Methodology}

Variables and data:

Following the literature, we measured the effectiveness with contribution to GDP. As a result, the dependent variable of our study is GDP. we used the government final expenditure as a proxy for fiscal policy. The money supply, on the other hand, is used as proxy for monetary policy. Therefore, the government final expenditure and money supply are independent variable.

The time series data ranging from 1960 to 2019 has been collected from the WDI (World Development Indicator) compiled by the World Bank.

\section{Econometric estimation method:}

The ARDL cointegration technique would be used if the underlying variables are of order I(0), I(1), or a combination of both (Pesaran \& Shin, 2012). It cannot be used if the underlying variablesare of order I. (2). Unit root tests, on the other hand, are recommended to avoid the failure of ARDL techniques and effort in order to avoid futilitarian efforts, as variables that integrate the order I(2) contribute to the failure of the methodology. If the trace, maximum eigenvalue, or F-statistics show that the variables (i.e. underlying variables) have a single long-run relationship, the ARDLapproach can be used instead of the Johansen and Juselius approach. In the form of a single equation, the ARDL m ethodology provides a coherent basis for measuring and estimating cointegration relations. The ARDL error correction representation becomes comparatively more effective when the F-statistics (Wald test) determines that there is a single long run relationship and the sample data size is small ( $n 30$ ) or finite. When there is only one cointegrating vector among the underlying variables, the ARDL model is reparameterized into ECM. The short-rundynamics and long-run relationship of the underlying variables are revealed by the re-parametrized result. The ARDL solution cannot be used where there are several long-run relationships.

The ARDL procedure follows 4 steps:

Step 1: Unit root test.

At the first stage, it is necessary to check the stationary properties of the time series variables with unit root tests. We choose to apply ADF unit root test. After we confirm that none of the variables are integrated of order two, we can proceed further to perform ARDL methodology.

Step 2 Bound testing: At the second stage, we test whether there is long-run relationship between variables.

For bound testing, the following model is estimated (Pesaran \& Shin, 2012):

$$
\Delta y_{t}=-\sum_{i=1}^{p-1} \gamma_{i}^{*} \Delta y_{t-1}+\sum_{j=1}^{k} \sum_{i=0}^{q_{j}-1} \Delta X_{j, t-i}{ }^{\prime} \beta_{j, i}{ }^{*}-\rho y_{t-1}-\alpha-\sum_{j=1}^{k} X_{j, t-1}{ }^{\prime} \delta_{j}+\epsilon_{t}
$$

To check if there is a long run relationship, we test the following null hypothesis: 


$$
\begin{aligned}
\rho & =0 \\
\delta_{1} & =\delta_{2}=\ldots=\delta_{k}=0
\end{aligned}
$$

Step 3: At the third step, we estimate the ARDL representation given by the following model (Pesaran \& Shin, 2012)

$$
\begin{aligned}
& p-1 \quad k \quad q_{j}-1 \\
& \Delta y_{t}=-\sum \gamma_{i}^{*} \Delta y_{t-1}+\sum \sum \Delta X_{j, t-i}{ }^{\prime} \beta_{j, i}{ }^{*}-\hat{\phi} E C_{t-1}+\epsilon_{t} \\
& i=1 \quad j=1 i=0 \\
& E C_{t}=y_{t}-\alpha-\sum_{j=1} X_{j, t^{\prime}} \hat{\theta}_{j} \\
& \hat{\phi}=1-\sum^{p} \hat{\gamma}_{i} \\
& i=1 \\
& p \\
& \gamma_{i}^{*}=\sum \hat{\gamma}_{m} \\
& m=i+1 \\
& q_{j} \\
& \beta_{j, i}^{*}=\sum \beta_{j, m}
\end{aligned}
$$

Step 4: At the step 4, we confirm the validity of the model. If the model passes the diagnostic tests such as, Normality test, Serial correlation test, and specification test, then the results found by the ARDL model are said to be valid.

\section{Results}

As has been described in methodology section, we followed 4 steps in producing the results. First we applied the unit root test using Augmented Dickey Fuller (ADF) test. The results are reported in appendix. The tables shows that all of the variables in ou rstudy are stationary at first order. This implies that we can apply ARDL. The conditions of applying ARDL would be violated if the variables were stationary of second order.

At the second step, we apply the bound test to check the long-run relationship among the variables. The ARDL bound test results are shown in table 1 . This test is used whether the variables are cointegrated, in another words, whether the variables have a long run relationship. We can see from 
table 1 that the F-statistics is 8.36 which is greater than the 1 percent level significance bound. This implies that the null hypothesis of no-cointegration have been rejected. Therefore, we can see that there is a long-run relationship between fiscal and monetary policies with economic growth in India.

\section{Table 1.ARDL Bounds Test}

Sample: 19642019

Included observations: 56

Null Hypothesis: No long-run relations hips exist

\begin{tabular}{|c|c|c|}
\hline Test Statistic & Value & $\mathrm{k}$ \\
\hline F-statistic & 8.356854 & 2 \\
\hline \multicolumn{3}{|c|}{ Critical Value Bounds } \\
\hline Significance & I0 Bound & I1 Bound \\
\hline $10 \%$ & 3.17 & 4.14 \\
\hline $5 \%$ & 3.79 & 4.85 \\
\hline $2.5 \%$ & 4.41 & 5.52 \\
\hline $1 \%$ & 5.15 & 6.36 \\
\hline
\end{tabular}

The figure 1 shows that procedure of selecting the optimal lag length of the ARDL model. We choose the model where $\mathrm{AIC}$ is minimum. The figure 1 shows that $\mathrm{AIC}$ is minimum when we choose $\operatorname{ARDL}(3,4,4)$. Therefore, the optimal model is $\operatorname{ARDL}(3,4,4)$

Figure 1. Choosing the correct model 
Akaike Information Criteria (top 20 models)

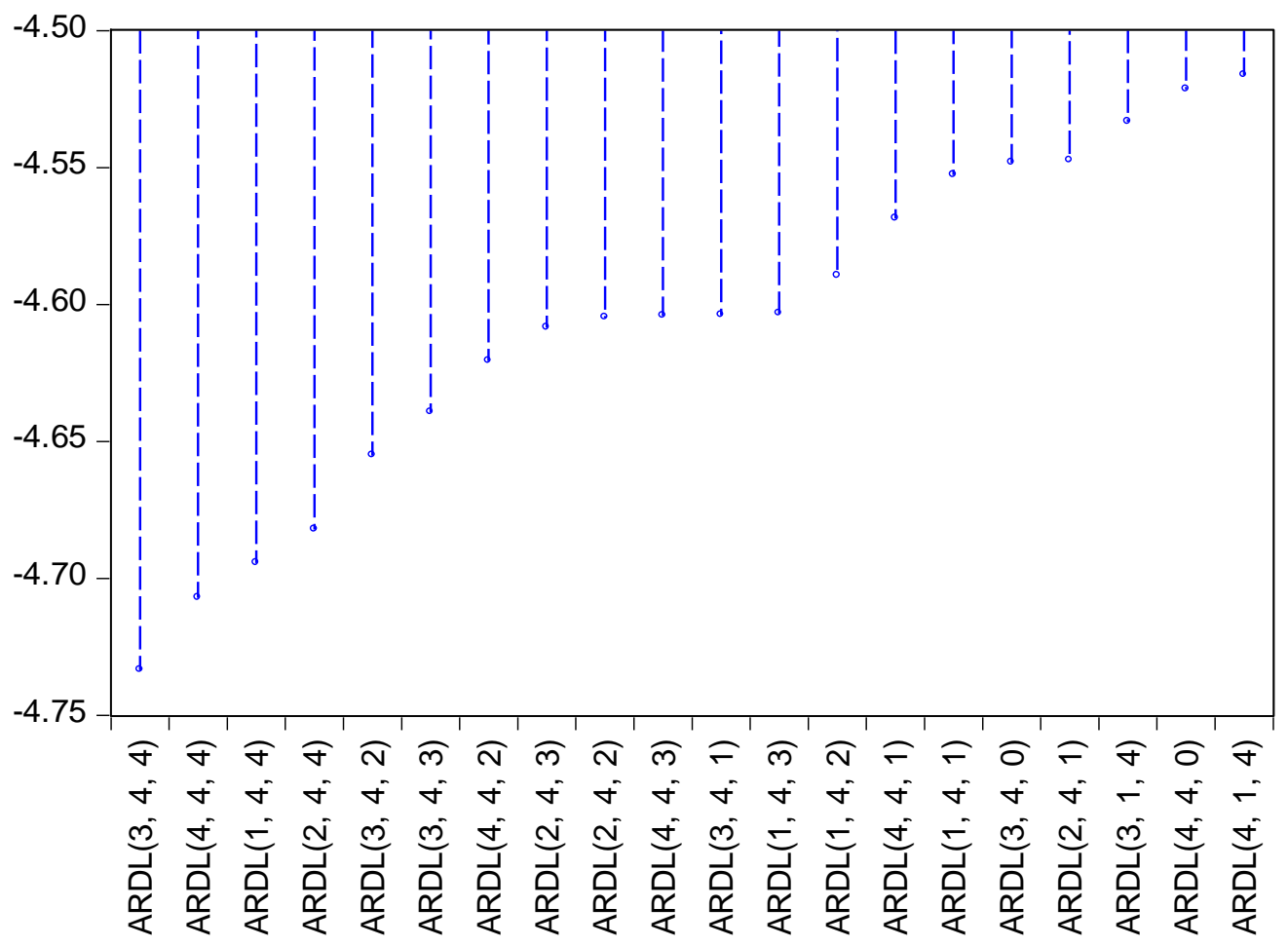

The third step involves the crucial parts of our analysis. Table 2 shows the results of the third step of our analysis. It shows the both short run and long run effects of fiscal and monetary policy on economic growth in Indian economy. The table shows that in the short run, the first two terms have $p$-value less than $5 \%$ significance level, meaning that the fiscal policy does not impact the economic growth in the immediate short runs. But, as time goes, the effect become positive and significant. Almost same applies for the short-run impacts of monetary policy: the first short run impact is insignificant, but later, the impact become positive and significant.

The lower panel of table 2 displays the long-run impact of monetary policy on economic growth. The results shows that the null hypothesis of no-impact have been rejected at $10 \%$ level of significance in case of fiscal policy. In the case of monetary policy, the null hypothesis of no-impact have been rejected at $5 \%$ level of significance. This scenario implies that both of the fiscal and monetary policies are effective in the Indian economy. However, the monetary policy seems more effective than the fiscal policy, both in short-run and in long-run.

Table 2 ARDL Cointegrating And Long Run Form

Dependent Variable:LGDP

Selected Model: ARDL(3, 4, 4)

Sample: 19602019

Included observations: 56

Short-run impacts 


\begin{tabular}{crrrr} 
Variable & Coefficient & Std. Error & t-Statistic & Prob. \\
\hline \hline D(LFISCAL) & -0.052731 & 0.088873 & -0.593331 & 0.5561 \\
D(LFISCAL(-1)) & -0.044027 & 0.125363 & -0.351192 & 0.7272 \\
D(LFISCAL(-2)) & 0.386454 & 0.123255 & 3.135398 & 0.0031 \\
D(LFISCAL(-3)) & 0.290042 & 0.075935 & 3.819602 & 0.0004 \\
D(LMONEY) & -0.123500 & 0.126175 & -0.978800 & 0.3333 \\
D(LMONEY(-1)) & 0.362526 & 0.200074 & 1.811959 & 0.2771 \\
D(LMONEY(-2)) & 0.469723 & 0.194158 & 2.419284 & 0.0200 \\
D(LMONEY(-3)) & 0.294206 & 0.121918 & 2.413139 & 0.0203 \\
CointEq(-1) & -0.109322 & 0.044455 & -2.459164 & 0.0181 \\
\hline \hline
\end{tabular}

Cointeq $=$ LGDP $-\left(-0.3957^{\star}\right.$ LFISCAL $+0.5463^{\star}$ LMONEY +22.5191$)$

\section{Long Run impacts}

\begin{tabular}{crrrr}
\hline \hline Variable & Coefficient & Std. Error & t-Statistic & Prob. \\
\hline \hline LFISCAL & 0.395731 & 0.608283 & 0.650570 & 0.0918 \\
LMONEY & 0.546324 & 0.241181 & 2.265207 & 0.0287 \\
C & 22.519132 & 8.492906 & 2.651523 & 0.0113 \\
\hline \hline
\end{tabular}

Diagnostic tests: At the last stage, we check the validity of our previous results with three different diagnostic tests: The 1) Breusch-Godfrey Serial Correlation LM Test, 2) Ramsey RESET tesr, and 3) JarqueBera normalitytest.

The table 3(a) shows the results of the serial correlation test. It can be seen from the table that the null hypothesis of "no serial correlation" can notbee rejected.. This implies that our estimated model is free from serial correlation problem.

Table 3(a) Breusch-Godfrey Serial Correlation LM Test:

\begin{tabular}{llll}
\hline \hline F-statistic & 0.146509 & Prob. F(2,40) & 0.8642 \\
Obs ${ }^{*}$ R-squared & 0.407243 & Prob. Chi-Square(2) & 0.8158 \\
\hline \hline
\end{tabular}

The table 3(b) shows the results of RamseyRESET test. It can be seen from the table that the null hypothesis of "no mis-s pecification" can not bee rejected. This implies that our estimated model is free from mis -specification problem.

Table 3(b): Ramsey RESET test

\begin{tabular}{lccc}
\hline \hline & Value & $\mathrm{df}$ & Probability \\
\cline { 2 - 4 } t-statistic & 0.847367 & 41 & 0.4017 \\
F-statistic & 0.718031 & $(1,41)$ & 0.4017 \\
\hline \hline F-test summary: & & & \\
& & & Mean \\
Test SSR & Sum of Sq. & $\mathrm{df}$ & Squares \\
\cline { 2 - 4 } Restricted SSR & 0.000301 & 1 & 0.000301 \\
Unrestricted SSR & 0.017494 & 42 & 0.000417 \\
& 0.017193 & 41 & 0.000419 \\
\hline \hline
\end{tabular}


The figure 2 displays the results of Jarque-Bera normality test. It can be seen from the figure that the null hypothesis of 'normality of distribution can notbee rejected. This implies that our estimated model is free from the problem of non-normality of residuals.

Figure 2: Normality test

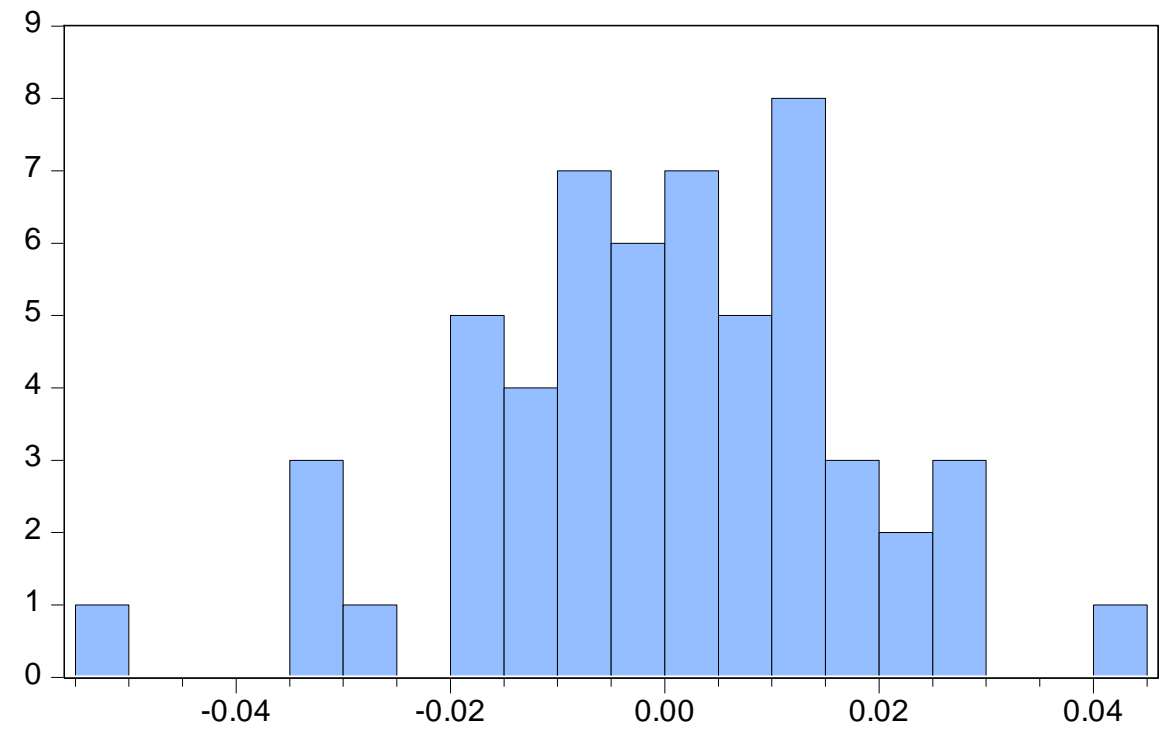

Series: Residuals

Sample 19642019

Observations 56

Mean

$-1.32 \mathrm{e}-15$

Median $\quad 0.001013$

Maximum $\quad 0.041758$

Minimum $\quad-0.054383$

Std. Dev. $\quad 0.017835$

Skewness $\quad-0.425482$

Kurtosis $\quad 3.597444$

Jarque-Bera 2.522520

Probability $\quad 0.283297$

\section{Conclusion}

The core objective of this study was to examine the efficacy of fiscal policy and monetary policy in India. We collected the time series data for India ranging from 1960 to 2019 from World Development Indicator (WDI). We applied the bound test to check the long-run relationship between fiscal policy, monetary policy and economic growth. The short-run and long-run effects of fiscal policy and monetary policy have been estimated using ARDL models. Following the literature, we measured the efficacy with contribution to GDP. As a consequence, the dependent variable of our study is GDP. we used the government final spending as a proxy for fiscal policy. The money supply, on the other hand, is used as proxy for monetary policy. Therefore, the government final expenditure and money supply are independent variable.

The findings showed that there is a long-run association between fiscal and monetary policies with economic development. The calculated short-run coefficients suggested that a few immediate short run effects of fiscal and monetary policies was negligible. However, the short-run impacts become important as time passes. The long-run results indicated that the long-run effects of both fiscal and monetary policies on economic growth are positive and important. More precisely, the GDP level rises if the money supply and government spending rise (Expansionary fiscal and monetary policies) (Expansionary fiscal and monetary policies). In the other hand, the GDP level decrease if the money supply and government spending decrease (contractionary fiscal and monetary policies) Therefore, this study suggest to use expansionary policies, whether monetary or fiscal, to boost the Indian economy.

\section{Appendix}




\section{Unit root test results}

Null Hypothesis: LGDP has a unit root Exogenous: Constant, Linear Trend Lag Length: 0 (Automatic - based on SIC, maxlag=10)

\begin{tabular}{lrrr}
\hline \hline & t-Statistic & Prob. $^{*}$ \\
\hline \hline Augmented Dickey-Fuller test statistic & -1.126719 & 0.9155 \\
\hline Test critical values: & $1 \%$ level & -4.121303 & \\
& $5 \%$ level & -3.487845 & \\
$10 \%$ level & -3.172314 & \\
\hline \hline
\end{tabular}

*MacKinnon (1996) one-sided p-values.

Augmented Dickey-Fuller Test Equation

Dependent Variable:D(LGDP)

Method: Least Squares

Date: 03/16/21 Time:01:22

Sample (adjusted): 19612019

Included observations: 59 after adjus tments

\begin{tabular}{lrlrr}
\hline \hline \multicolumn{1}{c}{ Variable } & Coefficient & Std. Error & t-Statistic & Prob. \\
\hline \hline \multicolumn{1}{c}{ LGDP(-1) } & -0.034441 & 0.030567 & -1.126719 & 0.2647 \\
C & 0.907446 & 0.778684 & 1.165359 & 0.2488 \\
@TREND("1960") & 0.002428 & 0.001562 & 1.553997 & 0.1258 \\
\hline \hline R-squared & 0.190500 & Mean dependent var & 0.050573 \\
Adjusted R-squared & 0.161589 & S.D. dependent var & 0.028220 \\
S.E. of regression & 0.025839 & Akaike info criterion & -4.424339 \\
Sum squared resid & 0.037389 & Schwarz criterion & -4.318702 \\
Log likelihood & 133.5180 & Hannan-Quinn criter. & -4.383103 \\
F-statistic & 6.589258 & Durbin-Watson stat & 2.240805 \\
Prob(F-statistic) & 0.002692 & & \\
\hline \hline
\end{tabular}

Null Hypothesis: D(LGDP) has a unit root

Exogenous: Constant, Linear Trend

Lag Length: 3 (Automatic - based on SIC, maxlag=10)

\begin{tabular}{lccc}
\hline \hline & t-Statistic & Prob. $^{*}$ \\
\hline \hline \multicolumn{2}{l}{ Augmented Dickey-Fuller test statistic } & -7.264424 & 0.0000 \\
\hline Test critical values: & 1\% level & -4.133838 & \\
& $5 \%$ level & -3.493692 & \\
$10 \%$ level & -3.175693 & \\
\hline \hline
\end{tabular}

*MacKinnon (1996) one-sided p-values.

Augmented Dickey-Fuller Test Equation

Dependent Variable:D(LGDP,2)

Method: Least Squares

Date: 03/16/21 Time:01:23 
Sample (adjusted): 19652019

Included observations: 55 after adjus tments

\begin{tabular}{crrrr}
\hline \hline Variable & Coefficient & Std. Error & t-Statistic & Prob. \\
\hline \hline D(LGDP(-1)) & -2.349512 & 0.323427 & -7.264424 & 0.0000 \\
D(LGDP(-1),2) & 1.049983 & 0.265297 & 3.957763 & 0.0002 \\
D(LGDP(-2),2) & 0.654575 & 0.195552 & 3.347319 & 0.0016 \\
D(LGDP(-3),2) & 0.435804 & 0.123683 & 3.523565 & 0.0009 \\
C & 0.059390 & 0.010837 & 5.480155 & 0.0000 \\
@TREND("1960") & 0.001864 & 0.000316 & 5.895138 & 0.0000 \\
\hline \hline R-squared & 0.705764 & Mean dependent var & -0.000562 \\
Adjusted R-squared & 0.675740 & S.D. dependent var & 0.039808 \\
S.E. of regression & 0.022668 & Akaike info criterion & -4.633034 \\
Sum squared resid & 0.025179 & Schwarz criterion & -4.414052 \\
Log likelihood & 133.4084 & Hannan-Quinn criter. & -4.548352 \\
F-statistic & 23.50660 & Durbin-Watson stat & 1.999105 \\
Prob(F-statistic) & 0.000000 & & \\
\hline \hline
\end{tabular}

Null Hypothesis: LFISCAL has a unit root

Exogenous: Constant

Lag Length: 1 (Automatic - based on SIC, maxlag=10)

\begin{tabular}{lccc}
\hline \hline & & t-Statistic & Prob. $^{*}$ \\
\hline \hline Augmented Dickey-Fuller test statistic & -0.347038 & 0.9107 \\
\hline Test critical values: & $1 \%$ level & -3.548208 & \\
& $5 \%$ level & -2.912631 & \\
& $10 \%$ level & -2.594027 & \\
\hline \hline
\end{tabular}

*MacKinnon (1996) one-sided p-values.

Augmented Dickey-Fuller Test Equation

Dependent Variable:D(LFISCAL)

Method: Least Squares

Date: 03/16/21 Time:01:24

Sample (adjusted): 19622019

Included observations: 58 after adjus tments

\begin{tabular}{lrrrr}
\hline \hline \multicolumn{1}{c}{ Variable } & Coefficient & Std. Error & t-Statistic & Prob. \\
\hline \hline \multicolumn{1}{c}{ LFISCAL(-1) } & -0.002000 & 0.005763 & -0.347038 & 0.7299 \\
D(LFISCAL(-1)) & 0.393462 & 0.125388 & 3.137949 & 0.0027 \\
\multicolumn{1}{c}{ C } & 0.087969 & 0.143215 & 0.614243 & 0.5416 \\
\hline \hline R-squared & 0.155898 & Mean dependent var & 0.063153 \\
Adjusted R-squared & 0.125204 & S.D. dependent var & 0.044734 \\
S.E. of regression & 0.041840 & Akaike info criterion & -3.459572 \\
Sum squared resid & 0.096284 & Schwarz criterion & -3.352998 \\
Log likelihood & 103.3276 & Hannan-Quinn criter. & -3.418059 \\
F-statistic & 5.079020 & Durbin-Watson stat & 1.817248 \\
Prob(F-statistic) & 0.009459 & & \\
\hline \hline
\end{tabular}

Null Hypothesis: D(LFISCAL) has a unit root

Exogenous: Constant

Lag Length: 0 (Automatic - based on SIC, maxlag=10) 


\begin{tabular}{lccc}
\hline \hline & & t-Statistic & Prob. $^{*}$ \\
\hline \hline Augmented Dickey-Fuller test statistic & -4.863219 & 0.0002 \\
\hline Test critical values: & 1\% level & -3.548208 & \\
& $5 \%$ level & -2.912631 & \\
& $10 \%$ level & -2.594027 & \\
\hline \hline
\end{tabular}

*MacKinnon (1996) one-sided p-values.

Augmented Dickey-Fuller Test Equation

Dependent Variable:D(LFISCAL,2)

Method: Least Squares

Date: 03/16/21 Time:01:24

Sample (adjusted): 19622019

Included observations:58 after adjus tments

\begin{tabular}{lrlrr}
\hline \hline \multicolumn{1}{c}{ Variable } & Coefficient & Std. Error & t-Statistic & Prob. \\
\hline \hline \multicolumn{1}{c}{ D(LFISCAL(-1)) } & -0.603631 & 0.124122 & -4.863219 & 0.0000 \\
\multicolumn{1}{c}{ C } & 0.038378 & 0.009481 & 4.047784 & 0.0002 \\
\hline \hline R-squared & 0.296932 & Mean dependent var & 0.000649 \\
Adjusted R-squared & 0.284377 & S.D. dependent var & 0.049070 \\
S.E. of regression & 0.041510 & Akaike info criterion & -3.491868 \\
Sum squared resid & 0.096495 & Schwarz criterion & -3.420818 \\
Log likelihood & 103.2642 & Hannan-Quinn criter. & -3.464192 \\
F-statistic & 23.65090 & Durbin-Watson stat & 1.823017 \\
Prob(F-statistic) & 0.000010 & & \\
\hline \hline
\end{tabular}

Null Hypothesis: LMONEY has a unit root

Exogenous: Constant

Lag Length: 2 (Automatic - based on SIC, maxlag=10)

\begin{tabular}{lccc}
\hline \hline & t-Statistic & Prob. $^{*}$ \\
\hline \hline Augmented Dickey-Fuller test statistic & -1.206290 & 0.6659 \\
\hline Test critical values: & $1 \%$ level & -3.550396 & \\
& $5 \%$ level & -2.913549 & \\
& $10 \%$ level & -2.594521 & \\
\hline \hline
\end{tabular}

*MacKinnon (1996) one-sided p-values.

Augmented Dickey-Fuller Test Equation

Dependent Variable:D(LMONEY)

Method: Least Squares

Date: 03/16/21 Time:01:25

Sample (adjusted): 19632019

Included observations:57 after adjus tments

\begin{tabular}{crrrr}
\hline \hline Variable & Coefficient & Std. Error & t-Statistic & Prob. \\
\hline \hline LMONEY(-1) & -0.001609 & 0.001334 & -1.206290 & 0.2331 \\
D(LMONEY(-1)) & 0.373214 & 0.126698 & 2.945700 & 0.0048 \\
D(LMONEY(-2)) & 0.365066 & 0.119410 & 3.057251 & 0.0035 \\
C & 0.083934 & 0.038944 & 2.155256 & 0.0357 \\
\hline \hline R-squared & 0.470065 & Mean dependent var & 0.143242
\end{tabular}




\begin{tabular}{lllr} 
Adjusted R-squared & 0.440068 & S.D. dependent var & 0.033138 \\
S.E. of regression & 0.024797 & Akaike info criterion & -4.488612 \\
Sum squared resid & 0.032589 & Schwarz criterion & -4.345240 \\
Log likelihood & 131.9254 & Hannan-Quinn criter. & -4.432892 \\
F-statistic & 15.67073 & Durbin-Watson stat & 2.098498 \\
Prob(F-statistic) & 0.000000 & & \\
\hline
\end{tabular}

Null Hypothes is: D(LMONEY) has a unit root

Exogenous: Constant

Lag Length: 1 (Automatic - based on SIC, maxlag=10)

\begin{tabular}{lccc}
\hline \hline & t-Statistic & Prob. $^{*}$ \\
\hline \hline Augmented Dickey-Fuller test statistic & -2.630918 & 0.0928 \\
\hline Test critical values: & 1\% level & -3.550396 & \\
& $5 \%$ level & -2.913549 & \\
& 10\% level & -2.594521 & \\
\hline \hline
\end{tabular}

*MacKinnon (1996) one-sided p-values.

Augmented Dickey-Fuller Test Equation

Dependent Variable:D(LMONEY,2)

Method: Least Squares

Date: 03/16/21 Time:01:26

Sample (adjusted): 19632019

Included observations: 57 after adjus tments

\begin{tabular}{lrlrr}
\hline \hline \multicolumn{1}{c}{ Variable } & Coefficient & Std. Error & t-Statistic & Prob. \\
\hline \hline D(LMONEY(-1)) & -0.281785 & 0.107105 & -2.630918 & 0.0111 \\
D(LMONEY(-1),2) & -0.336411 & 0.117515 & -2.862695 & 0.0060 \\
\multicolumn{1}{c}{ C } & 0.040870 & 0.015628 & 2.615215 & 0.0115 \\
\hline \hline R-squared & 0.305191 & Mean dependent var & 0.000144 \\
Adjusted R-squared & 0.279457 & S.D. dependent var & 0.029335 \\
S.E. of regression & 0.024901 & Akaike info criterion & -4.496614 \\
Sum squared resid & 0.033483 & Schwarz criterion & -4.389085 \\
Log likelihood & 131.1535 & Hannan-Quinn criter. & -4.454825 \\
F-statistic & 11.85958 & Durbin-Watson stat & 2.057858 \\
Prob(F-statistic) & 0.000054 & & \\
\hline \hline
\end{tabular}

\section{References}

Ajisafe, R. A., \& Folorunso, B. A. (2002). The relative effectiveness of fiscal and monetary policy in 
macroeconomic management in Nigeria. The African Economic and Business Review, 3(1), 2340.

Arestis, P., \& Sawyer, M. (2004). On the effectiveness of monetary policy and of fiscal policy. Review of Social Economy. https://doi.org/10.1080/0034676042000296218

Balducci, R. (2005). Fiscal policy and economicgrowth. In Innovation, Unemployment and Policy in the Theories of Growth and Distribution . https://doi.org/10.4337/9781845428167.00021

Bernanke, B. S., \& Blinder, A. S. (1988). Credit, money, and aggregate demand. American Economic Review.

Biljana, R., \& Tamara, R. (2013). The effectiveness of monetary and fiscal policy in Serbia. Industrija. https://doi.org/10.5937/industrija41-4011

Bishai, D. M., \& Kung, Y. T. (2007). Macroeconomics. In Macrosocial Determinants of Population Health. https://doi.org/10.1007/978-0-387-70812-6_8

Bruno, V., \& Shin, H. S. (2015). Capital flows and the risk-taking channel of monetary policy. Journal of Monetary Economics. https://doi.org/10.1016/j.jmoneco.2014.11.011

Cannon, E. (2004). Advanced Macroeconomics. The Economic Journal. https://doi.org/10.1111/j.0013-0133.2004.191_16.x

Cukierman, A. (2013). Monetary policy and institutions before, during, and after the global financial crisis. Journal of FinancialStability. https://doi.org/10.1016/j.jfs.2013.02.002

Davig, T., \& Leeper, E. M. (2011). Monetary-fiscal policy interactions and fiscal stimulus. European Economic Review. https://doi.org/10.1016/j.euroecorev.2010.04.004

Ferris, J. S. (2013). Fiscal policy. In The Elgar Companion to Public Choice, Second Edition . https://doi.org/10.4337/9781849806039.00028

Frazer, W. J., \& Ward, R. A. (1967). Monetary Theory and Policy. The Journal of Finance. https://doi.org/10.2307/2326030

Gertler, M., \& Karadi, P. (2015). Monetary policy surprises, credit costs, and economic activity. American EconomicJournal: Macroeconomics. https://doi.org/10.1257/mac. 20130329

Hur, S.-K. (2007). Measuring the effectiveness of fiscal policy in Korea. In Fiscal Policy and Management in East Asia (pp. 63-93). University of Chicago Press.

Jawadi, F., Mallick, S. K., \& Sousa, R. M. (2016). Fiscal and monetary policies in the BRICS: A panel VAR approach. Economic Modelling. https://doi.org/10.1016/j.econmod.2015.06.001

Jha, S., Mallick, S. K., Park, D., \& Quising, P. F. (2014). Effectiveness of countercyclical fiscal policy: Evidence from developing Asia. Journal of Macroeconomics. https://doi.org/10.1016/j.jmacro.2014.02.006

Khemani, S. (2007). Does delegation of fiscal policy to an independent agency make a difference? Evidence from intergovernmental transfers in India. Journal of Development Economics. https://doi.org/10.1016/j.jdeveco.2006.04.001

Özer, M., \& Karagöl, V. (2018). Relative effectiveness of monetary and fiscal policies on output growth in Turkey: an ARDL bounds test approach. Equilibrium. Quarterly Journal of Economics and Economic Policy, 13(3), 391-409.

Pesaran, M. H., \& Shin, Y. (2012). An Autoregressive Distributed-Lag Modelling Approach to Cointegration Analysis. In Econometrics and Economic Theory in the 20th Century. 
https://doi.org/10.1017/ccol521633230.011

Rendahl, P. (2016). Fiscal policy in an unemployment crisis. Review of Economic Studies. https://doi.org/10.1093/restud/rdv058

Simon, M. (2012). EFFECTIVENESS OF FISCAL POLICYIN ECONOMIC GROWTH: THE CASE OF ZIMBABWE. International Journal of Economics and Research , 3(6), 93-99.

Skidelsky, R. (2019). The general theory of employment, interest and money. In The Elgar Companion to John Maynard Keynes. https://doi.org/10.4337/9781788118569.00039

Zhu, C. J., \& Warner, M. (2019). The emergence of Human Resource Management in China: Convergence, divergence and contextualization. Human Resource Management Review. https://doi.org/10.1016/j.hrmr.2017.11.002 